\title{
Should Equity Be a Goal of Economic Policy?
}

IMF Fiscal Affairs Department

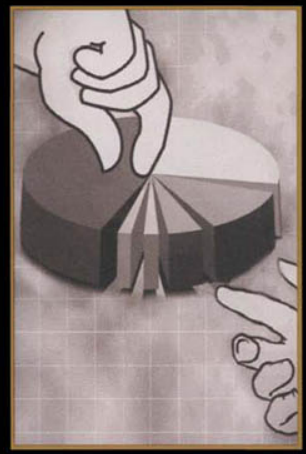


ECONOM I C I S S UES

\section{Should Equity Be a Goal of Economic Policy?}

IMF Fiscal Affairs Department

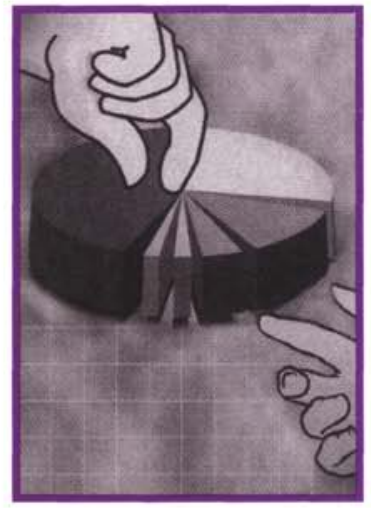


(C)1998 International Monetary Fund

Production: IMF Graphics Section

Cover design: Massoud Etemadi

Typesetting: Victor Barcelona, Julio R. Prego

ISBN 1-55775-790-9

ISSN $1020-5098$

Published December 1998

To order IMF publications, please contact:

International Monetary Fund, Publication Services 700 19th Street, N.W., Washington, D.C. 20431, U.S.A.

Tel: (202) 623-7430 Telefax: (202) 623-7201

E-mail: publications@imf.org

Internet: http://www.imf.org 


\section{Preface}

The Economic Issues series aims to make available to a broad readership of nonspecialists some of the economic research being produced on topical issues by IMF staff. The series draws mainly from IMF Working Papers, which are technical papers produced by IMF staff members and visiting scholars, as well as from policyrelated research papers.

This Economic Issue is a summary version of an Issues Paper circulated at the IMF Conference on Economic Policy and Equity, held on June 8-9, 1998, at IMF headquarters. It was prepared by the IMF Fiscal Affairs Division with contributions from Sanjeev Gupta, Benedict Clements, Robert Gillingham, Christian Schiller, Marijn Verhoeven, Rosa Alonso-Terme, and Alexandros Mourmouras; both the Issues Paper and this pamphlet are available on the IMF's Internet site at http://www.imf.org. The conference volume Economic Policy and Equity will be published in early 1999, when it can be purchased from IMF Publication Services. 
This page intentionally left blank 


\section{Should Equity Be a Goal of Economic Policy?}

O ver the past decade, global output has grown by more than 3 percent a year and inflation has slowed in most regions. The fruits of this g rowth have not been shared equally, however, and income disparities have grown in many countries, developed as well as developing. One of the most pressing issues facing policymakers today is how to respond to these trends. To what extent are growth and equity complementary, and to what extent is there a trade-off between the two?

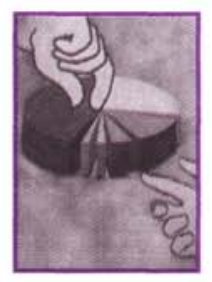

\section{Why Is Equity Important?}

The answers to these questions depend on how equity is defined. Different societies have different perceptions of what is equitable, and these social and cultural norms shape the policies they will adopt to promote equity. Although there is a consensus that extreme inequality of income, wealth, or opportunity is unfair and that efforts should be made to raise the incomes of the poorest members of society, there is little agreement on the desirability of greater income equality for its own sake or on what constitutes a fair distribution of income. Equity issues are especially knotty because they are inextricably intertwined

CInternational Monetary Fund. Not for Redistribution 
with social values. Nonetheless, economic policymakers are devoting greater attention to them for a number of reasons:

- Some societies view equity as a worthy goal in and of itself because of its moral implications and its intimate link with fairness and social justice.

- Policies that promote equity can help, directly and indirectly, to reduce poverty. When incomes are more evenly distributed, fewer individuals fall below the poverty line. Equity-enhancing policies, particularly such investment in human capital as education, can, in the long run, boost economic growth, which, in turn, has been shown to alleviate poverty.

- Heightened awareness of the discrimination suffered by certain groups because of their gender, race, or ethnic origin has focused attention on the need to ensure that these groups have adequate access to government services and receive fair treatment in the labor market.

- Many of today's policies will affect the welfare of future generations, which raises the issue of intergenerational equity. For instance, the provision of very generous pension benefits to today's retirees could be at the expense of tomorrow's retirees-an important issue in many transition and industrial countries.

- Policies that promote equity can boost social cohesion and reduce political conflict. To be effective, most policies require broad political support, which is more likely to be forthcoming when the distribution of income is seen as fair. However, macroeconomic adjustment that entails growth-enhancing structural reforms such as privatization may increase unemployment and worsen inequality in the short run. In such circumstances, well-targeted social safety nets to shelter the consumption levels of the poor are critically important.

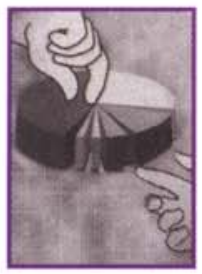




\section{Growing Inequality}

Income inequality varies greatly from region to region. It is greatest in Latin America and sub-Saharan Africa, and lowest in Eastern Europe; other regions fall between these two extremes. In Latin America, the average "Gini coefficient"-the most commonly used measure of inequality, with 0 representing perfect equality and 1 representing total inequality-is nearly 0.5 . The average Gini coefficient in sub-Saharan Africa is slightly lower, but there is considerable variation among countries. Income inequality has a regional dimension in both Africa and Latin America-average incomes are significantly higher in urban areas than in rural areas.

In recent years, income inequality has been increasing in a large number of countries. This increase has been most striking in the economies in transition to market-oriented systems, where the average Gini coefficient had been about 0.25 until the late 1980 s; by the mid-1990s, it had risen to more than 0.30. Although this may not appear to be a large increase, it is quite significant for such a short period of time, since Gini coefficients tend to be relatively stable in countries over long periods. In the past decade, income inequality has also increased in several Group of Seven countries (for example, Germany, Japan, the United Kingdom, and the United States) and is beginning to rise in some East Asian countries (China and Thailand).

Much of the debate about income distribution has centered on wage earnings. But wages tell only part of the story. The distribution of wealth (and, by implication, capital income) is more concentrated than labor income. In Africa and Latin America, unequal ownership of land has been identified as an important factor in the overall distribution of income. Furthermore, in recent years, there has been a shift from labor to capital income (including from self-employment) in many countries. In transition economies, this shift has been due primarily to the privatization of state-owned assets. The analysis of trends in nonlabor income in countries with well-developed capital markets and pension funds is more complicated. Pension funds and other financial institutions receive a sizable portion of capital income, and the share of capital income in total household income typically changes over the life cycle of the individuals in the household. 


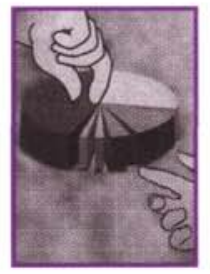

\section{Is Globalization to Blame?}

Globalization has linked the labor, product, and capital markets of economies around the world. Increased trade, capital and labor movements, and technological progress have led to greater specialization in production and the dispersion of specialized production processes to geographically distant locations. Developing countries, with their abundant supply of unskilled labor, have a comparative advantage relative to developed countries in the production of unskilled-labor-intensive goods and services. As a result, production of these goods in developed countries has come under increased competitive pressure. Economic theory tells us this should apply downward pressure on the relative compensation of unskilled workers in developed countries and upward pressure on the compensation of their counterparts in developing countries.

On the basis of this theory, some have claimed that globalization is to blame for growing income inequality in developed countries. Others argue that the widening gap between the wages of skilled workers and unskilled workers in the industrial countries is due to the development and dispersion of skill-intensive technologies rather than to increased trade. Several empirical studies have tried to gauge the relative importance of trade versus technological progress for the decline in wages of unskilled workers in developed countries. Estimates of the contribution of increased trade to the total increase of the wage differential between unskilled and skilled workers range from negligible to 50 percent. This large variation reflects the structure of production in developed countries and the share of the labor market that is in direct competition with low-skilled workers in developing countries. 
The debate regarding the effect of globalization on income distribution in developing countries mirrors the debate on developed countries. Although, all other things being equal, increased openness would be expected to boost the relative wage of unskilled workers in developing countries, experience has been mixed. Evidence suggests that the relative wages of unskilled workers rose in East Asian countries in the 1960s and 1970s but fell in Latin America in the 1980s and early 1990s. There are two possible explanations for why wages fell in Latin America: first, the opening up of developing Asian countries-Bangladesh, India, China, Indonesia, and Pakistan-where unskilled labor is even more abundant; second, the availability of new production technologies that are biased toward skilled labor.

Globalization's effect on income distribution appears to be determined to some extent by a country's level of development and the technologies available to it. Similarly, exposure to international competition may change institutions (for example, trade unions), and thereby affect income distribution. Some observers contend that, because of the mobility of capital, globalization limits the ability of union workers to achieve a "union wage premium," decreasing the bargaining power of workers vis-à-vis capital. In addition, globalization may lead to sharp short-run changes in the distribution of income, as barriers to trade are reduced and the distribution of production is reallocated among sectors.

Many argue that globalization makes it more difficult for governments to carry out equitable policies. Increasingly mobile capital and labor have limited the ability of governments to levy taxes and transfer them to those affected by globalization. To the extent that capital is more mobile than labor, the incidence of taxes to finance safety nets for those affected by globalization is shifted to labor.

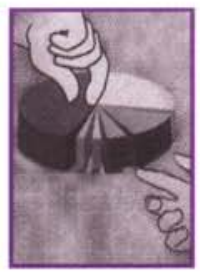




\section{Policy Responses}

How much countries have focused on promoting equity, and the strategies they have adopted, vary widely. Some countries have actively promoted the use of public resources to improve the situation of the bottom tier of the income distribution. Others have focused on the top percentiles with highly progressive taxes. Yet others-concerned that policies targeting the poor may result in economic inefficiencies and distortions that retard growth-have taken an indirect approach, seeking to help low-income families by stimulating overall economic growth.

In Latin America during the 1980s, policymakers' primary goal was achieving sustainable growth, and a viable balance of payments and structural reforms were seen as critical to achieving this goal. Growth has also been one of the primary goals of the transition economies, but the strategy in these countries has included policies aimed at helping groups likely to be hurt by the transition. Such policies have included distributing shares of privatized enterprises, adapting social policy instruments to protect vulnerable groups, and erecting social safety nets (for example, targeted subsidies, cash compensation in lieu of subsidies, severance pay and retraining for retrenched public sector employees, and public works programs). However, the lack of budgetary resources has hampered implementation of these policies.

Fiscal policy-taxation and spending-is a government's most direct tool for redistributing income, in both the short and the long run. Nevertheless, the effect of redistributive tax policies, especially in the face of globalization, has been small. It is widely accepted that policymakers should focus on developing a broadly based, efficient, and easily administered tax system with moderate marginal rates. An important subsidiary issue is how to distribute the burden of taxation so the system is seen as fair and just. Achieving these various goals is naturally complex and politically sensitive.

The expenditure side of the budget has offered better opportunities than the tax side for redistributing income. The link between income distribution and social spending-especially spending on health and education, through which governments can influence the 
formation and distribution of human capital-is particularly strong, and public investment in human capital can be an efficient way to reduce income inequality over the long run.

The resources governments can and should devote to social expenditures depends on various factors, including the tax-to-GDP ratio and the resources devoted to other spending. Theory tells us public expenditure should displace private expenditure only when it yields higher social benefits. Priority should be given to the most productive public expenditures, and unproductive public expenditures-for example, excessive military spending, wages for an overstaffed civil service, and budgetary transfers to inefficient public enterprises-should be curtailed. And evidence suggests that civil service reform and the privatization of services that can be better provided by the private sector-especially if accompanied by a reallocation of expenditures to the social sectors-are likely to be both growth- and equity-enhancing, particularly in developing countries, where public sector employees come primarily from the middleand upper-middle-income classes.

Outlays on health and education can improve the existing pattern of income distribution, depending to a large extent on the allocation of expenditures on various economic sectors. Studies show that spending on basic health care and primary education is far more effective in reaching the poor than spending on higher education or hospital-based curative care; it reduces disparities in human capital across income groups and can narrow income inequality in the long run. Studies also show that, in countries without some form of pooling of health risks, serious illnesses are the single most important factor driving families into poverty.

Although many view fiscal policy as the principal vehicle for assisting low-income groups and those affected adversely in the short run by reform programs, a number of countries have introduced labor market policies to influence income distribution-the rationale being that relative wages exert a strong influence on overall income inequality. Many European countries have opted for high minimum wages, generous unemployment benefits, and a wide range of job-protection measures. Although these policies can result in labor market rigidities, advocates maintain that they help achieve 
a socially desirable redistribution of income; opponents argue that they discourage new investment and dampen job creation and growth. The United States, with its alternative approach to labor market flexibility, has achieved high employment levels, but the cost may be larger inequalities. To mitigate any potentially adverse effects of market flexibility on low-wage workers, the United States has introduced wage subsidies that simultaneously redistribute income and promote employment. Given the potentially large impact of labor market policies on earnings, these competing visions of the labor market are central to the debate over income inequality in many developing and newly industrialized countries.

Governments can also indirectly affect income levels and distribution through monetary policy and the overall stance of macroeconomic policy. For example, high inflation tends to curtail economic growth and widen income inequality. Trade liberalization-especially when it occurs in developing countries that have had such restrictive trade policies as taxation of agricultural exports and protective tariffs against imports-may boost economic growth and lead to more equitable conditions. Currency devaluations may also have implications for equity, particularly in low-income countries, where the poor are often concentrated in the agriculture-intensive export sector and middle- and upper-income urban dwellers tend to be more dependent on imports.

Also important is whether governments should focus on outcomes-such as decreasing the number of people living in povertyor on ensuring that all members of society have equal opportunities. In extreme cases of income inequality, outcomes are clearly critical. In other cases, setting up a level playing field may be all that is necessary, and greater emphasis can be placed on policies that facilitate mobility between income classes, and on ensuring that income and wealth are acquired justly and fairly. To promote equality of opportunity, governments can adopt such measures as deregulating the economy, setting up strong and accountable institutions and a wellfunctioning judicial system, reducing opportunities for corrupt practices (curbing corruption can directly reduce income inequality, as the gains from corrupt practices tend to be captured by the well-todo), and providing adequate access to health and education services. 


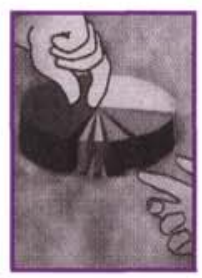

\section{Obstacles to Overcome}

Governments seeking to carry out equity-oriented policies face a number of obstacles:

- First and foremost is the financing required: high levels of spending on targeted programs may not be consistent with a sustainable macroeconomic framework.

- Governments in many developing countries, where a large share of the population is engaged in rural and informal sector activities, may be unable to reach the most vulnerable groups. The rural and informal sectors may have limited interaction with formal sector institutions, including the government, complicating the delivery of government assistance (for example, cash transfers).

- Similarly, a lack of administrative capacity may hamper redistributive efforts. For example, tax evasion is a severe problem in countries with weak tax administration, making it difficult for governments to use the tax system as a vehicle to finance redistributive policies.

- Political constraints-low-income groups typically have less political power than other interest groups-may impede efforts to reallocate spending toward the poor or redistribute land or other assets.

- Legal impediments may also prevent governments from taking measures to promote equity-for example, constitutional rules on revenue sharing may limit the amount of resources a central government can allocate to redistributive policies. 


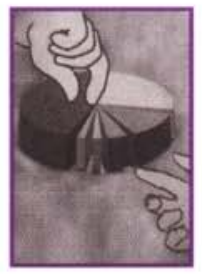

\section{Summary}

Despite widespread economic expansion, income gaps have widened during the past decade in many parts of the world, including in the industrial countries. This trend has heightened concerns about the treatment of equity in the formulation of economic policy. Equity and growth can be complementary: some policies that promote equity-particularly investment in human capital—can boost growth in the long run and thus alleviate extreme poverty, increase social cohesion, and reduce the scope for political conflict. Policy choices are not always so easy, however: when growth and equity do not go hand in hand, when and how should governments intervene?

The strategies that countries have adopted vary widely. The most effective tool for redistributing income is fiscal policy. And of the two sides of the budget-taxation and spending - the expenditure side, especially spending on health and education, has offered the better opportunities for reducing income inequality over the long term. But governments have also pursued income redistribution through labor market measures, monetary policy, and the overall stance of macroeconomic policy.

An important question is whether governments should focus on outcomes (such as decreasing broad measures of income inequality) or on ensuring that all members of society have equal opportunities (for example, through policies that facilitate mobility among income classes and by setting up a well-functioning judicial system and reducing the scope for corruption). In all these efforts, governments face difficult obstacles: lack of financial resources, difficult-to-reach 
target groups, weak administrative capacity, and legal and political constraints. A consensus is forming nevertheless that governments should sometimes intervene to ensure not only that the size of the pie increases, but that everybody gets a fair share. 


\section{The Economic Issues Series}

1. Growth in East Asia: What We Can and What We Cannot Infer. Michael Sarel. 1996.

2. Does the Exchange Rate Regime Matter for Inflation and Growth? Atish R. Ghosh, Anne-Marie Gulde, Jonathan D. Ostry, and Holger Wolf. 1996.

3. Confronting Budget Deficits. 1996.

4. Fiscal Reforms That Work. C. John McDermott and Robert F. Wescott. 1996.

5. Transformations to Open Market Operations: Developing Economies and Emerging Markets. Stephen H. Axilrod. 1996.

6. Why Worry About Corruption? Paolo Mauro. 1997.

7. Sterilizing Capital Inflows. Jang-Yung Lee. 1997.

8. Why Is China Growing So Fast? Zuliu Hu and Mohsin S. Khan. 1997.

9. Protecting Bank Deposits. Gillian G. Garcia. 1997.

10. Deindustrialization - Its Causes and Implications. Robert Rowthorn and Ramana Ramaswamy. 1997.

11. Does Globalization Lower Wages and Export Jobs? Matthew J. Slaughter and Phillip Swagel. 1997.

12. Roads to Nowhere: How Corruption in Public Investment Hurts Growth. Vito Tanzi and Hamid Davoodi. 1998.

13. Fixed or Flexible? Getting the Exchange Rate Right in the 1990 s. Francesco Caramazza and Jahangir Aziz. 1998.

14. Lessons from Systemic Bank Restructuring. Claudia Dziobek and Ceyla Pazarbaşıoğlu. 1998.

15. Inflation Targeting as a Framework for Monetary Policy. Guy Debelle, Paul Masson, Miguel Savastano, and Sunil Sharma. 1998.

16. Should Equity Be a Goal of Economic Policy? IMF Fiscal Affairs Department. 1998. 
Sanjeev Gupta is Chief, Expenditure Policy Division, of the IMF's Fiscal Affairs Department. He holds degrees from Delhi, Oxford, and Simon Fraser Universities.

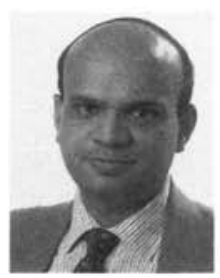

Benedict Clements, currently Senior Economist in the IMF's European I Department, was educated at the University of St. Thomas and the University of Notre Dame.

Robert Gillingham, a consultant in the Expenditure Policy Division of the Fiscal Affairs Department, has degrees from Haverford College and the University of Pennsylvania.

Christian Schiller, a graduate of the University of Mainz, is Deputy Division Chief, Expenditure Policy Division, of the Fiscal Affairs Department.

Marijn Verhoeven, Economist in the Expenditure Policy Division of the Fiscal Affairs Department, was educated at Tilburg University.

Rosa Alonso-Terme, a graduate of the University of Barcelona and the Johns Hopkins University, is currently an Economist in the Fiscal Affairs Department.
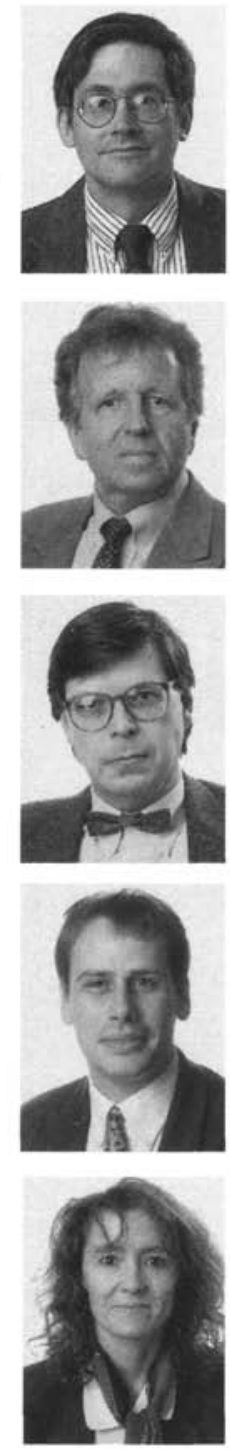

Alexandros Mourmouras is an Economist in the Expenditure Policy Division of the Fiscal Affairs Department. He holds degrees from Harvard College and the University of Minnesota.

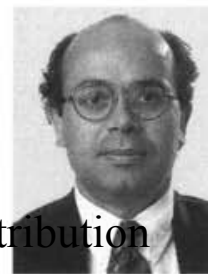

